\title{
Assessment of Pattern of CD4+ T-Cell Recovery Among Human Immunodeficiency Virus Patients After Initiation of Highly Active Antiretroviral Therapy at Arsi Negelle Health Center, Ethiopia: A Retrospective Cross-Sectional Study
}

This article was published in the following Dove Press journal: HIVIAIDS - Research and Palliative Care

\section{Sileshi Barasa Gelba \\ Surafel Fikadu \\ Alemawi Kindie Legesse \\ Hiwot Wubet \\ Mihret Alemu Yesuf \\ Wondwossen Abera \\ Temesgen Bizuayehu Wube}

School of Medical Laboratory Science, College of Medicine and Health Sciences, Hawassa University, Hawassa, Ethiopia
Correspondence: Temesgen Bizuayehu Wube P.O. Box: 1560, Hawassa, Ethiopia Tel +25l-9|6-60-45-5|

Email temesgenbizuayehu2@gmail.com
Background: Antiretroviral therapy has resulted in significant reductions in HIV-associated complications by recovering the CD4+ $\mathrm{T}$ cell count. Some patients may not be successful in attaining this result, and some may achieve it only after many years of treatment.

Objective: This study aimed to assess CD4 $+\mathrm{T}$ cell recovery and non-response patterns among HAART experienced HIV-positive patients at the Arsi Negelle health center.

Methods: This was a retrospective cross-sectional study conducted among HAART experienced HIV/AIDS patients at Arsi Negelle Health Center from January 01, 2014 to January 06, 2019. Data were documented to a data retrieval form and analyzed with SPSS version 20 Linear regression analysis was used to identify predictors of CD4 count change. A P-value of $<0.05$ was considered significant.

Results: The total median of CD4+ T cells increased from 257 cells/uL at the baseline to 382 cells/uL after 6 months, then to 591 cells/uL after 60 months of treatment. The non-response rate was $22.1 \%$ and $23.8 \%$ among the total study participants and children of less than 15 years, respectively. Only baseline CD4+ T cell was associated with a change in CD4+ T cell count.

Conclusion: From our study, we can conclude that CD4 $+\mathrm{T}$ cell count has recovered in most of the study participants after HAART initiation. The immunological non-response rate of study participants was $22.1 \%$ after 12 months on HAART and $7.2 \%$ at the end of the study. Keywords: CD4+ T-cell recovery, immunological non-response rate, Arsi Negelle, Ethiopia

\section{Introduction}

\section{Background}

Expanding access to treatment is at the heart of new treatment targets for 2020 that aimed to end the AIDS epidemic as a public health danger by 2030. The 90-90-90 target is a plan which includes $90 \%$ of the people living with HIV to know their HIV status, $90 \%$ of the people who know their HIV status to receive ART and $90 \%$ of the people receiving ART to have suppressed viral loads. ${ }^{1}$ The goal of treatment with antiretroviral drugs is to inhibit viral replication while minimizing toxicities and side effects associated with the available drugs. ${ }^{2}$ The inhibition of virus replication permits restoration of the immune system thereby preventing or delaying the clinical progression of HIV disease. ${ }^{3,4}$ 
HAART has resulted in substantial reductions in HIVassociated morbidity and mortality. ${ }^{4,5}$ changing an HIV diagnosis into a manageable chronic infection in Ethiopia even though there is a regional variation in the extent of its benefit. HAART also promoted growth, prolonged survival and improved the quality of life of all HIV-infected patients. ${ }^{2}$ Studies from a different region of Ethiopia found that HAART can sustain virological efficacy for a substantial length of time and enhance immunological recovery irrespective of age. ${ }^{6,7}$ Despite the scale-up of ART, early mortality is a major challenge. A systematic review from Ethiopia found that $5-40.8 \%$ of the patients died during the follow-up period. More than half (50-68.8\%) of the deaths occurred within 6 months of initiating ART. ${ }^{8}$ Most HIV-infected patients' complications can be improved within a few months after the initiation of HAART. ${ }^{9}$ One of those complications that can be reversed by HAART is immunological deficiencies associated with untreated HIV infection. ${ }^{2}$

Even if most patients on HAART can eventually attain an optimal CD4+ T-cell count outcome shortly after initiation, some may fail to achieve this result, and some of them achieve only after many years of HAART. ${ }^{10}$ Some studies observed that one-third of successfully treated patients appear not to reach a normal CD4+ T-cell count within five years ${ }^{11}$ and low CD4+ T-cell count for a longer period may increase the risk of complication. ${ }^{12}$ Studies in Ethiopia observed immunologic failure to be the most common complication among HAART experienced patients. ${ }^{13}$ Patients with low CD4+ T-cell at baseline have the highest risk of failure to achieve an optimal immunological recovery. The effectiveness of ART treatment will be dependent on different factors such as baseline $\mathrm{CD} 4+$, nutritional status, and adherence.

Even though some studies in Ethiopia address the immunological none response rate and CD4 recovery, ${ }^{7,14}$ to the best of our knowledge, there are no studies from the study area concerning rates of CD4 + T-cells recovery and rates of immunological non-response to ART among HIV-infected patients. Therefore, we conducted a retrospective study to assess the trends of CD4 cell recovery among HIV patients after the initiation of antiretroviral therapy in Negelle, southeastern Ethiopia.

\section{Methods and Materials}

\section{Study Area and Design}

This was a retrospective cross-sectional study conducted among HAART experienced HIV/AIDS patients at Arsi
Negelle health center during the year January 01, 2014January 06, 2019. Arsi Negelle is located in the West Arsi zone, southeastern Ethiopia.

\section{Data Collection}

Data of 195 HAART experienced study participants who have uninterrupted every six months CD4+ T-cell count on their record were collected during the year January 1, 2014-January 06, 2019 using a pretested structured questionnaire. A baseline, 6-monthly CD4 + T-cells count, patients' sex, age, weight, WHO clinical stage and other basic information was collected from medical records. We retrieved the absolute $\mathrm{CD} 4+\mathrm{T}$-cell count which is the number of CD4+ T cells $/ \mu \mathrm{L}$. Those records which missed a single every six month CD4+ T-cell result were excluded.

\section{Statistical Analysis}

All Data were pulled out from the patients' medical records and then recorded to data retrieval form, and then entered into Epidata 3.4 software for clean-up. Data were entered and analyzed using statistical package for social sciences (SPSS) for Windows version 20. Categorical variables were summarized as frequencies and percentages while numerical variables with non-normal distribution were summarized as median and IQR. Changes in CD4 + T-cells count every six months were also examined and stratified based on baseline CD4 + T-cells count. Finally, the result was presented using tables, bar graphs, and line graphs. Linear regression analysis was used to identify predictors of CD4 count change. A P-value of less than 0.05 was considered statistically significant.

\section{Data Quality Assurance}

The training was given to data collectors on how to review registration logbooks and maintain the confidentiality of the data. ART nurses working in the ART clinics were recruited as data collectors. Data quality was assured by collecting data with appropriate care and by applying the double-entry method. In addition to this, the quality of data was achieved by crosschecking of data collected. Data collection forms were examined for completeness, consistency, coding errors, accuracy, and clarity and missing values, by investigators before they were entered.

\section{Results \\ Socio-Demographic and Clinical Characteristics}

From a total of 195 study participants, 122 (62.6\%) were female and the majority (34.4\%) of the study participants are in the age group of 15-30 years with a median (IQR) age of 30 (20-38) 
years. Around $21.5 \%$ of the study participants are children of less than 15 years. $73.3 \%$ of the participants are either who did not take formal education or, are attending primary school (Table 1).

During this study, $31.3 \%$ and $8.2 \%$ of the study participants are under the WHO clinical stage I and IV, respectively. Regarding the baseline CD4+ T-cell count, the median CD4+ T-cell count was 257 (171-413, IQR) cells/uL. 36.4\% had CD4+ T-cell count $<50$ cells $/ \mu \mathrm{L}, 30.8 \%$ had $51-200$ cells $/ \mu \mathrm{L}$ and $15.4 \%$ had $351-500$ cells $/ \mathrm{uL}$. None of them had a baseline CD4+ T-cell count of $>500$ cells (Table 1 ).

Additionally, $6.2 \%$ of patients had been infected with TB before starting HAART and the majority (59\%) of them are on Tenofovir (TDF)+ Lamivudine (3TC)+ Efavirenz (EFV) which are a standard first-line HAART regimen.

\section{A Change in CD4+ T-Cell Count After Six-Month Treatment}

From the total study participants of age less than 15 years, 23 (54.8\%) of them had a CD4+ T-cell count change of $>500$ cell count after 6-month of treatment. $31.3 \%, 21.5 \%$ and $33.3 \%$ of the study participants of the age group of 15-30, 31-45 and above 45 , respectively, had a CD4+ T change of greater than 500 cell count and the difference in change in CD4+ T-cell count after 6 months of treatment among different age groups was statistically significant $(\mathrm{P}=0.03)$ (Table 2 ).

$12.2 \%$ male and $19.8 \%$ female participants had a change in CD4+ $\mathrm{T}$ count of less than 200 cell count at 6-month treatment, and $31.1 \%$ male and $34.7 \%$ female had a CD4+ T count of greater than 500 cell change from the baseline (Table 2), though the distribution was not statistically significant $(\mathrm{P}=0.2) .47 .5 \%$ of stage I study participants had a change in $\mathrm{CD} 4+\mathrm{T}$ count of greater than 500cells after a 6-month treatment (Table 2).

From those study participants with less than 50 cells at baseline, $40.8 \%$ of them still had a CD4+ T count change of fewer than 200 cells, and only $8.5 \%$ of them did achieve greater than 500 cells (Table 2). The difference in a change in CD4+ $\mathrm{T}$ count after 6 months of treatment based on the baseline $\mathrm{CD} 4+\mathrm{T}$ count was statistically significant $(\mathrm{P}<0.001)$.

\section{Trends of Median CD4+ T-Cell Count Recovery of the Study Participants}

Figure 1 shows the median 60 months CD4+ T-cell count increase. Along with HAART duration, CD4+ $\mathrm{T}$ count continually increased, even long after HAART initiation. The median of CD4+ T increased from 257 cells/uL at the
Table I Socio-Demographic and Clinical Characteristics of Study Participants Attending Arsi Negelle Health Center from January I, 2014 to January 06, 2019

\begin{tabular}{|c|c|c|c|}
\hline Variable & Category & Frequency & Percentage \\
\hline Median (IQR) Age & & $30(20-38)$ & \\
\hline \multirow[t]{4}{*}{ Age } & $<15$ & 42 & 21.5 \\
\hline & $15-30$ & 67 & 34.4 \\
\hline & $31-45$ & 65 & 33.3 \\
\hline & $>45$ & 21 & 10.8 \\
\hline \multirow[t]{2}{*}{ Sex } & Male & 73 & 37.5 \\
\hline & Female & 122 & 62.5 \\
\hline \multirow[t]{3}{*}{ Weight } & $<40$ & 52 & 26.7 \\
\hline & $40-60$ & 109 & 55.9 \\
\hline & $>60$ & 34 & 17.4 \\
\hline \multirow[t]{5}{*}{ Educational status } & No formal & 72 & 36.9 \\
\hline & Education & & \\
\hline & Primary & 71 & 36.4 \\
\hline & Secondary & 37 & 19.0 \\
\hline & Tertiary & 15 & 7.7 \\
\hline \multirow[t]{5}{*}{ Marital status } & Single & 51 & 26.2 \\
\hline & Married & 80 & 41.0 \\
\hline & Divorced & 34 & 17.4 \\
\hline & Separated & 11 & 5.6 \\
\hline & Widowed & 19 & 9.7 \\
\hline \multirow[t]{4}{*}{ WHO staging } & Stage I & 60 & 31.3 \\
\hline & Stage II & 63 & 32.3 \\
\hline & Stage III & 56 & 28.2 \\
\hline & Stage IV & 16 & 8.2 \\
\hline \multirow{6}{*}{$\begin{array}{l}\text { Baseline CD4+ } \\
\text { T cell (in cells/uL) }\end{array}$} & Median (IQ) & $257(|7|-4 \mid 3)$ & \\
\hline & $\leq 50$ & 71 & 36.4 \\
\hline & $51-200$ & 60 & 30.8 \\
\hline & $20 I-350$ & 34 & 17.4 \\
\hline & $35 I-500$ & 30 & 15.4 \\
\hline & $>500$ & 0 & \\
\hline \multirow[t]{2}{*}{ TB } & Yes & 12 & 6.2 \\
\hline & No & 183 & 93.8 \\
\hline \multirow{4}{*}{$\begin{array}{l}\text { Drugs } \\
\text { (HAART regimen) }\end{array}$} & $\mathrm{TDF}+3 \mathrm{TC}+\mathrm{EFV}$ & 115 & 59.0 \\
\hline & $A Z T+3 T C+N V P$ & 42 & 21.5 \\
\hline & $A Z T+3 T C+E F V$ & 31 & 15.9 \\
\hline & $T D F+3 T C+N V P$ & 7 & 3.6 \\
\hline
\end{tabular}

Abbreviations: CD, Cluster of Differentiation; IQR, Interquartile range; TB, Tuberculosis; WHO, World Health Organization; HAART, highly active antiretroviral therapy.

baseline to $382 \mathrm{cells} / \mathrm{uL}$ after 6-month treatment, then to 591 cells/uL after 60 months of treatment.

The sixty months of change in the median CD4+ T-cell count after the commencement of HAART is plotted in Figure 2. After 6 months of HAART initiation, 16.9\%, 25.6\% and $65 \%$ of them remained less than 200 cells/uL, between 200-350 and $>500$ cells/uL, respectively. After 60 months of 
Table 2 A Change in CD4+ T Cell Count from the Baseline to 6 Months After HAART Initiation

\begin{tabular}{|c|c|c|c|c|c|c|}
\hline \multirow[t]{2}{*}{ Variable } & \multirow[t]{2}{*}{ Category } & \multicolumn{4}{|c|}{ Change in CD4+ T Cell After 6-Month Treatment } & \multirow[t]{2}{*}{ P-value } \\
\hline & & $<200$ & $20 I-350$ & $35 I-500$ & $>500$ & \\
\hline Age & $\begin{array}{l}<15 \\
15-30 \\
31-45 \\
>45\end{array}$ & $\begin{array}{l}6(14.3) \\
14(20.9) \\
8(12.3) \\
5(23.8)\end{array}$ & $\begin{array}{l}6(14.2) \\
16(23.9) \\
24(36.9) \\
4(19.0)\end{array}$ & $\begin{array}{l}7(16.7) \\
16(23.9) \\
19(29.2) \\
5(23.8)\end{array}$ & $\begin{array}{l}23(54.8) \\
2 \mid(3 \mid .3) \\
14(2 \mid .5) \\
7(33.3)\end{array}$ & 0.03 \\
\hline Sex & $\begin{array}{l}\text { Male } \\
\text { Female }\end{array}$ & $\begin{array}{l}9(12.2) \\
24(19.8)\end{array}$ & $\begin{array}{l}19(25.7) \\
31(25.6)\end{array}$ & $\begin{array}{l}23(31.1) \\
24(19.8)\end{array}$ & $\begin{array}{l}23(31.1) \\
42(34.7)\end{array}$ & 0.2 \\
\hline Weight & $\begin{array}{l}\leq 40 \\
40-60 \\
>60\end{array}$ & $\begin{array}{l}7(13.5) \\
23(21.1) \\
3(8.8)\end{array}$ & $\begin{array}{l}12(23.1) \\
33(30.3) \\
5(14.7)\end{array}$ & $\begin{array}{l}9(17.3) \\
25(22.9) \\
13(38.2)\end{array}$ & $\begin{array}{l}24(46.2) \\
28(25.7) \\
13(38.2)\end{array}$ & 0.03 \\
\hline Education & $\begin{array}{l}\text { No formal education } \\
\text { Primary } \\
\text { Secondary } \\
\text { Tertiary }\end{array}$ & $\begin{array}{l}\text { I3 (18.I) } \\
\text { II (I5.5) } \\
8(21.6) \\
\text { I (6.7) }\end{array}$ & $\begin{array}{l}\text { I8 }(25.0) \\
\text { I8 (25.4) } \\
\text { II (29.7) } \\
3(20.0)\end{array}$ & $\begin{array}{l}16(22.2) \\
19(26.8) \\
7(18.9) \\
5(33.3)\end{array}$ & $\begin{array}{l}25(34.7) \\
23(32.4) \\
11(29.7) \\
6(40.0)\end{array}$ & 0.9 \\
\hline Marital Status & $\begin{array}{l}\text { Single } \\
\text { Married } \\
\text { Divorced } \\
\text { Separated } \\
\text { Widowed }\end{array}$ & $\begin{array}{l}\text { II }(21.6) \\
13(16.2) \\
4(11.8) \\
1(9.1) \\
4(21.1)\end{array}$ & $\begin{array}{l}8(15.7) \\
22(27.5) \\
10(29.4) \\
5(45.5) \\
5(26.3)\end{array}$ & $\begin{array}{l}\text { II }(21.6) \\
20(25.0) \\
10(29.4) \\
2(18.2) \\
4(21.1)\end{array}$ & $\begin{array}{l}21(41.2) \\
25(31.2) \\
10(29.4) \\
3(27.3) \\
6(31.6)\end{array}$ & 0.8 \\
\hline WHO Stage & $\begin{array}{l}\text { Stage I } \\
\text { Stage II } \\
\text { Stage III } \\
\text { Stage IV }\end{array}$ & $\begin{array}{l}7(11.5) \\
9(14.3) \\
12(21.8) \\
5(31.2)\end{array}$ & $\begin{array}{l}10(16.4) \\
18(28.6) \\
16(29.1) \\
6(37.5)\end{array}$ & $\begin{array}{l}\text { I5 (24.6) } \\
20(31.7) \\
\text { II }(20.0) \\
\text { I }(6.2)\end{array}$ & $\begin{array}{l}29(47.5) \\
16(25.4) \\
16(29.1) \\
4(25.0)\end{array}$ & 0.047 \\
\hline Baseline CD4+ Count & $\begin{array}{l}\leq 50 \\
5 I-200 \\
20 I-350 \\
35 I-500 \\
>500\end{array}$ & $\begin{array}{l}29(40.8) \\
4(6.7) \\
0 \\
0 \\
0\end{array}$ & $\begin{array}{l}3 \mathrm{I}(43.7) \\
\text { I7 (28.3) } \\
\text { I (2.9) } \\
\text { I (3.3) } \\
0\end{array}$ & $\begin{array}{l}5(7.0) \\
28(46.7) \\
13(38.1) \\
1(3.3) \\
0\end{array}$ & $\begin{array}{l}6(8.5) \\
\text { II (I8.3) } \\
20(58.8) \\
28(93.3) \\
0\end{array}$ & $<0.001$ \\
\hline TB Infection & $\begin{array}{l}\text { Yes } \\
\text { No }\end{array}$ & $\begin{array}{l}3(25.0) \\
30(16.4)\end{array}$ & $\begin{array}{l}4(33.3) \\
46(25.1)\end{array}$ & $\begin{array}{l}3(25.0) \\
44(24.0)\end{array}$ & $\begin{array}{l}2(16.7) \\
63(34.4)\end{array}$ & 0.6 \\
\hline HAART Regimen & $\begin{array}{l}T D F+3 T C+E F V \\
A Z T+3 T C+N V P \\
A Z T+3 T C+E F V \\
T D F+3 T C+N V P\end{array}$ & $\begin{array}{l}17(14.8) \\
7(16.7) \\
7(22.6) \\
2(28.6)\end{array}$ & $\begin{array}{l}32(27.8) \\
7(16.7) \\
8(25.8) \\
3(42.9)\end{array}$ & $\begin{array}{l}28(24.3) \\
12(28.6) \\
6(19.4) \\
I(14.3)\end{array}$ & $\begin{array}{l}38(33.0) \\
16(38.1) \\
10(32.3) \\
1(14.3)\end{array}$ & 0.8 \\
\hline
\end{tabular}

Abbreviations: CD, cluster of differentiation; TB, tuberculosis; WHO, World Health Organization; HAART, highly active antiretroviral therapy.

follow up, these percentages were improved to $0.5 \%, 5.6 \%$, and $75.4 \%$, respectively. The greatest CD4+ T count rise was seen after 6 months of treatment where $65 \%$ of the study participants reached a CD4+ T level of $>500$ cells/uL (Figure 2).

\section{Median CD4+ T Count of Children of $<15$ Years Old}

Figure 3 shows a median CD4+ T count of children of less than 15 years old. The baseline median CD4+ T count was
400cells/uL. This count rose to 562.5 cells after 6 months of treatment, then to $625 \mathrm{CD} 4+\mathrm{T}$ after 60 months of treatment.

\section{Immunological Non-Response Rate of Study Participants}

The immunological non-response rate was defined as an increase of $<50$ cells/uL after HAART treatment. ${ }^{14}$ The immunological non-response rate of the study participants is shown in Figure 3. The percentages of patients who failed 


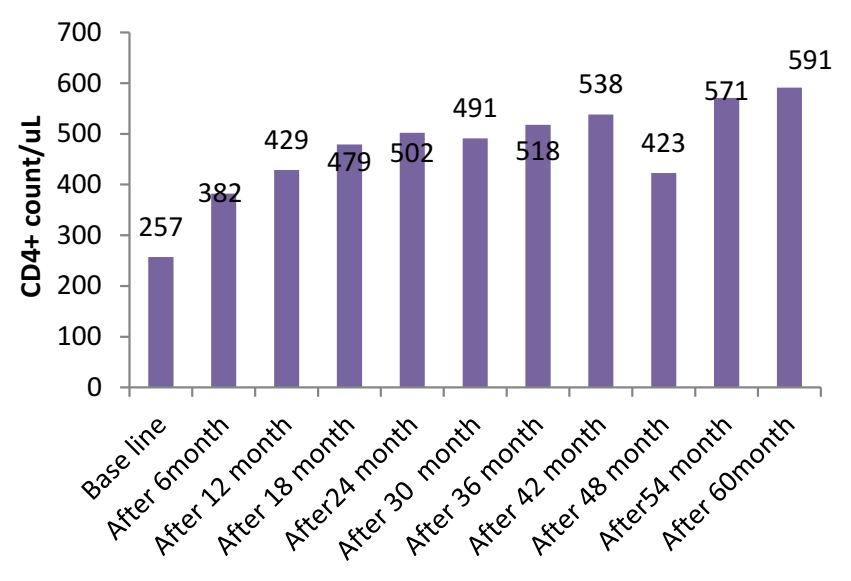

Figure I Median CD4+ T cell change of the study participants during 60 months of HAART treatment at Arsi Negelle Health Center from January 0I, 2014 to January 06, 2019.

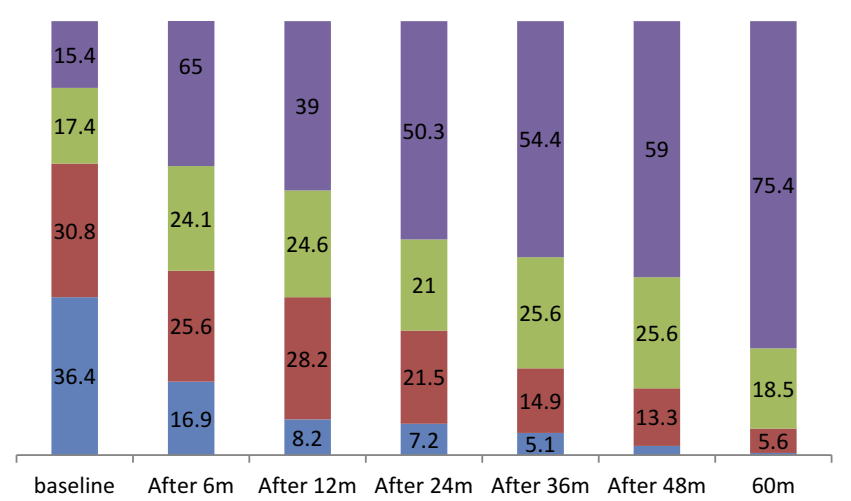

$>500$ cells/uL

$351-500$ cells/uL

201-350 cells/uL

$<200$ cells/uL

Figure 2 CD4+ T cell recovery of 195 study participants on HAART over 60 months of follow-up at Arsi Negelle Health Center from January 0I, 2014 to January 06, 2019.

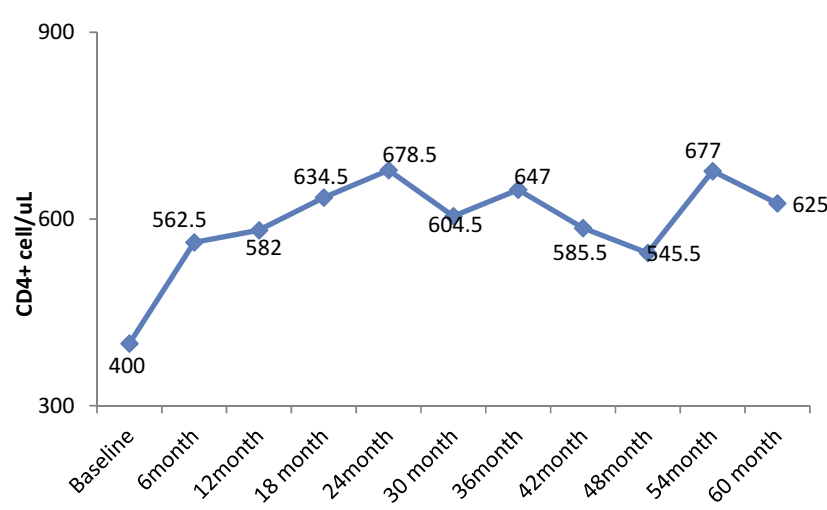

Figure 3 Median CD4+ T cell count of children less than 15 years old at Arsi Negelle Health Center from January 0I, 2014 to January 06, 2019. to attain an absolute CD4+ T-cell count increase of at least 50 cells $/ \mathrm{uL}$ at 12 months was $22.1 \%$. This percentage drops to $13.8 \%$ after 36 and 42 months on treatment, and $7.2 \%$ after 54 months and 60 months of treatment (Figure 4).

\section{Non-Response Rate of the Study Participants of Age $\geq 15$ Years Old}

Figure 5 indicates the non-response rate of the study participants' age $\geq 15$ years old. The immunological nonresponse rate decreased continuously from 6 months of treatment to the 60 months. The rate was very high during 6 months after HAART initiation (26.7\%), continue to decrease to $17 \%$ after 1 year HAART treatment, then to 9.7\% after 3years, hitting the lowest none-response rate during the 54th and the 60th month of treatment with $4.1 \%$ (Figure 5). The mean non-response rate of study participants of age greater than 15 years old was $12.2 \%$.

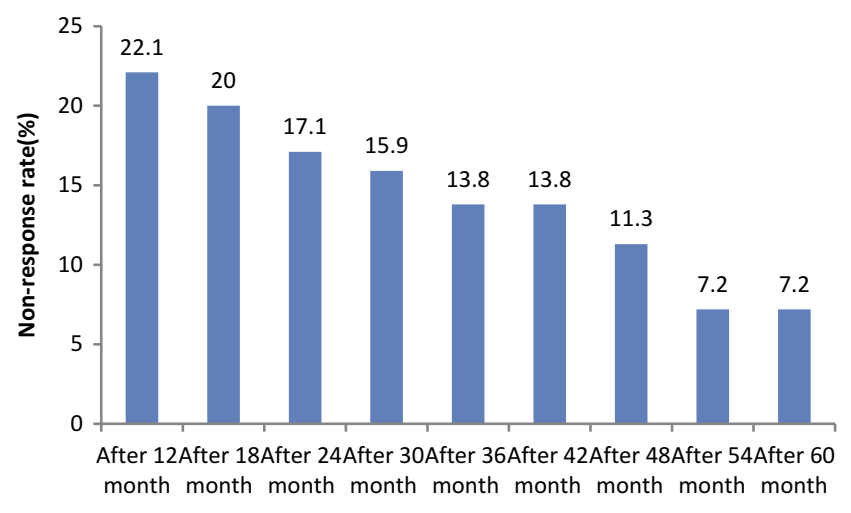

Figure 4 Immunological non-response rate of study participants from 12 to 60 months after HAART commencement at Arsi Negelle Health Center from January 0I, 2014 to January 06, 2019.

Abbreviation: NRR, a none response rate.

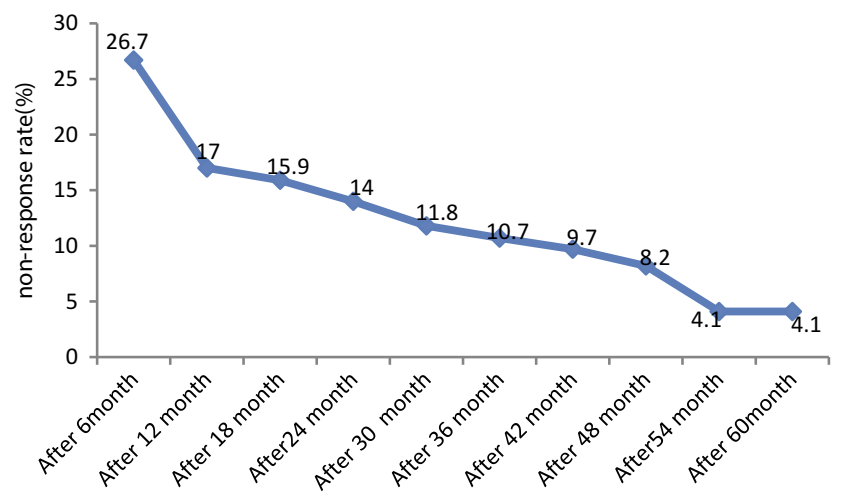

Figure $\mathbf{5}$ Nonresponse rate of the study participants aged greater than 15 years old at Arsi Negelle Health Center from January 0I, 2014 to January 06, 2019. Abbreviation: NRR, a none response rate. 


\section{Immunological Non-Response Rate of Children $<15$ Years Old}

The non-response rate of children of less than 15 years hits its highest rate after 1 year of treatment $(23.8 \%)$, decreasing to $14.3 \%$ for the 48th, 54th and 60th consecutive month of CD4+ $\mathrm{T}$ measurements (Figure 6). The mean non-response rate of children of less than 15 years was $16.93 \%$.

\section{Contribution of Children of Less Than 15 Years None-Response Rate to the Total Immunological Non-Response Rate}

From a total of $22.1 \%$ immunological non -responsiveness after 12 months of HAART treatment, only $5.1 \%$ of it was because of children of less than 15 years old. The highest contribution of children to the total immunological nonresponsiveness was after 60 months of HAART treatment, which is $3.1 \%$ out of $7.2 \%$ of the total non-response rate (Figure 7).

\section{Factors Associated with a Change in CD4 + T-Cell Count}

To assess factors associated with a change in CD4+ T-cell at the $60^{\text {th }}$ month from the baseline we used linear regression, and variables such as age, sex, baseline CD4+ T-cell count, baseline the WHO stage, TB infection, and ART regimen are inserted. Only baseline CD4+ T-cell was associated with a change in CD4+ T-cell count after 60 months of follow-up (Table 3).

\section{Discussion}

HAART has been shown to improve the quality of life of HIV-infected patients by increasing the CD4+ T-cell

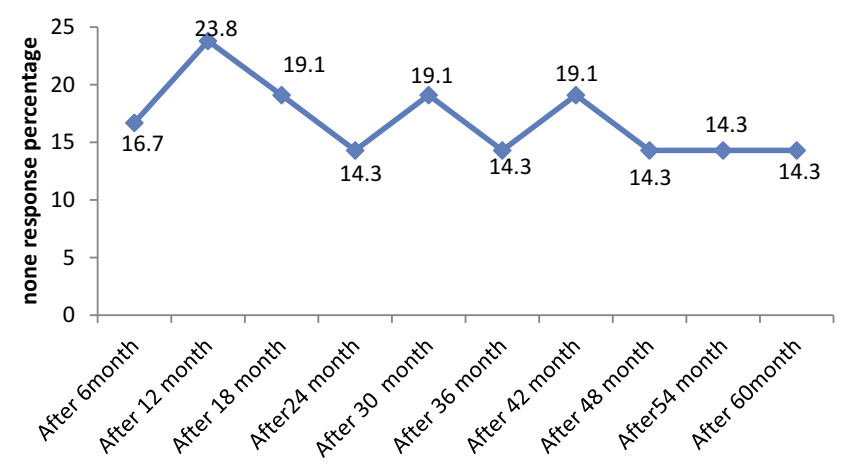

Figure 6 Immunological non response rate of children less than 15 years old at Arsi Negelle Health Center from January 01, 2014 to January 06, 2019.

Abbreviation: NRR, a none response rate.

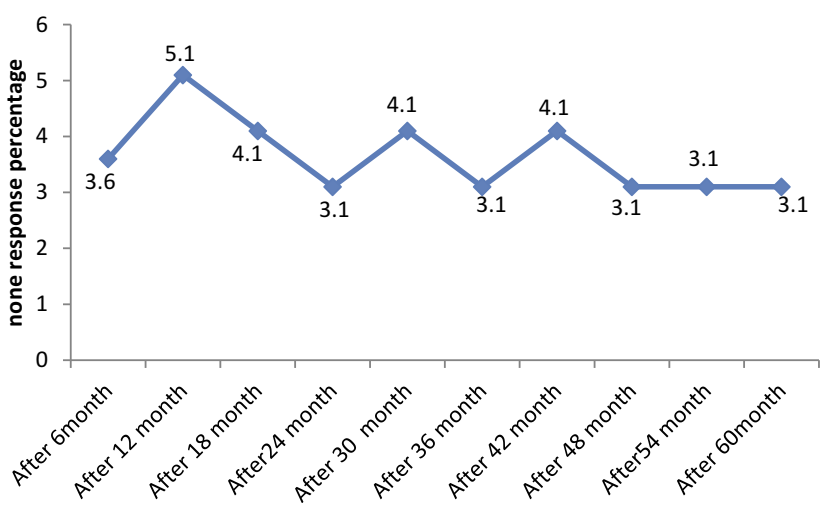

Figure 7 Contribution of children non response rate to the total immunological non-response rate at Arsi Negelle Health Center from January 0I, 2014 to January 06, 2019.

lymphocyte count and by reducing viral load to undetectable levels. This leads to a remarkable reduction in AIDSrelated morbidity and mortality rates. This was a retrospective study carried out to assess CD4+ T-cell recovery, none-response rate and factor associated with a change in CD4+ T-cell count among HAART experienced HIV-positive patients at Arsi Negelle health center.

Majorities $(62.6 \%)$ of the study participants are female; a reflection of a fact that women under the sub-Saharan region are at increased risk for HIV/AIDS than males. The majority $(19.8 \%$ Vs $12.2 \%)$ of females had a CD4+ T-cell change of less than 200 cells than males after 6 months of treatment. This implies an increased immunological non-responsiveness among female patients which is supported by another study $^{7,15}$ though some studies will not support this. ${ }^{16,17}$

$84.6 \%$ of the study participants had a CD4+ of $<350$ cells/uL before HAART initiation. Although the median CD4 count at the time of HAART initiation is increasing, it remains significantly lower than 350 cells/uL in almost all settings, including high-income countries. ${ }^{18,19}$ Improvements in overall CD4+ T-cell count among the patients were seen over time until 60 months of followup. This finding is supported by other retrospective longitudinal study conducted in eastern Ethiopia ${ }^{20}$ and another a seven-year randomized control trial. ${ }^{21}$ Our study population showed no major CD4 + T-cells increase beyond the first year of treatment. This could be because of poor response among patients with low CD4 counts, and possibly poor thymic function. ${ }^{22}$

The greatest increment of CD4+ T-cell count lift seen after 6 months could be because of a quick drop in viral load following the inhibition of viral replication in 
Table 3 Univariate Linear Regression for Factor Associated with a Change in CD4+ T- Cell after 60 Months of Follow-Up among HAART Experienced Study Participants at Arsi Negelle Health Center from January 0I, 2014 to January 06, 2019

\begin{tabular}{|c|c|c|c|c|}
\hline & \multicolumn{3}{|l|}{ Change in $\mathrm{CD}_{4}+$} & \multirow[b]{2}{*}{ B $(95 \% \mathrm{Cl})$} \\
\hline & Standard Error & $r^{2}$ & P-value & \\
\hline Age (in year) & 0.6 & 0.006 & 0.3 & $0.7(-5-1.8)$ \\
\hline Sex & II.I & 0.002 & 0.5 & $7(-14.9-29.1)$ \\
\hline Baseline CD4+ $T$ cell & 0.07 & 0.1 & $<0.001$ & $3.2(3.0-3.4)$ \\
\hline Baseline WHO stage & 17.2 & 0.007 & 0.2 & $19.6(-14.2-53.5)$ \\
\hline TB Infection & 68.2 & 0 & 0.9 & $0.78(-134-135.2)$ \\
\hline ART regimen & 18.7 & 0 & 0.8 & 4.I $(-32.8-4 \mid .1)$ \\
\hline Educational status & 17.6 & 0 & 0.8 & $4.4(-30.3-39.1)$ \\
\hline Marital status & 13.6 & 0.01 & 0.1 & $21.3(-5.5-48.1)$ \\
\hline Weight (in Kg) & 0.9 & 0.002 & 0.5 & $0.6(-1.3-2.5)$ \\
\hline
\end{tabular}

Abbreviations: ART, anti retroviral therapy; CD, cluster of differentiation; TB, tuberculosis; WHO, World Health Organization.

productively infected cells during the first 2 weeks of HAART. This drop is associated with an increase in the CD4+ T-cell lymphocyte count. ${ }^{23,24}$ This finding was also in line with other studies. ${ }^{14,21}$ The median of CD4+ T-cell at baseline was 257 cells/uL which was higher than a baseline median of the study done in Hawassa university referral hospital (167cells/uL). ${ }^{14}$ The difference could be explained by the fact that our study included all participants of the age group.

A high proportion of patients exhibited immunologic nonresponse (22.1\%) after 12 months of treatment, a proportion similar to that observed in a study conducted in Northern Ethiopia $(22.7 \%)^{7}$ but higher than the study done in Hawassa, southern Ethiopia (19.3\%). ${ }^{14}$ These results confirm that even though HAART permits the reconstitution of the immune system, all HAART experienced may not achieve a significant gain of CD4+ T-cell counts. ${ }^{16,23}$ This could be explained by the fact that opportunistic infections and/or immune reconstitution inflammatory syndrome (IRIS) may develop, as well as early adverse drug reactions, such as drug hypersensitivity, especially in the first 3 months of ART. ${ }^{25}$

From the present study, a CD4+ T-cell change was associated with a baseline CD4+ T-cell count $(\mathrm{P} \leq 0.001)$ which is in line with the study done in Gonder ${ }^{26}$ and Hawassa but in contrast with a retrospective study done by reviewing 459 medical records which reported that the outcomes of HIV patients did not differ by baseline CD4+ T-cell count. ${ }^{27}$

\section{Conclusion}

From our study, we can conclude that HAART has helped the majority of the study participants to recover their CD4+ T-cell count; though some of the study participants are unable to recover their CD4+ T-cell count. The immunological non-response rate of study participants was $22.1 \%$ after 12 months on HAART and $7.2 \%$ at the end of the study.

\section{Limitations of the Study}

The retrospective study design limited our ability to gather data about factors that may influence the none-response rate. The small sample size was also another limitation of this study.

\section{Abbreviations}

AIDS, Acquired Immune Deficiency Syndrome; ART, Antiretroviral Treatment; CD4, Cluster Differentiation 4; HAART, Highly Active Anti-Retroviral Treatment; HIV, Human Immunodeficiency Virus; IQR, Inter Quartile Range; WHO, World Health Organization.

\section{Ethics Approval and Consent to Participate}

Ethical approval was obtained from the Institutional Review Board (IRB) of Hawassa University. As the study was retrospective, the IRB waived that the research could be done based on record review without contacting patients. A letter of support was obtained from the Arsi Negelle Health Bureau. Permission letters were obtained from the Arsi Negelle Health Center. All information was kept confidential and no individual identifiers were collected.

\section{Data Sharing Statement}

The data that support the findings of this study are at the Arsi Negelle Health Office but not publicly available. However, the data are available from the authors upon reasonable request and with the permission of the Arsi Negelle Health Office ethics committee. 


\section{Acknowledgments}

We would like to thank the Arsi Negelle Health Office for their support during data collection. We also would like to thank the data collectors and those who directly or indirectly had a contribution to this study.

\section{Author Contributions}

All authors have contributed to the conception, design, acquisition of data, data analysis, and drafting or revising the article, gave final approval of the version to be published, and agree to be accountable for all aspects of the work.

\section{Funding}

This research received no specific grant from any funding agency in the public, commercial or not-for-profit sectors.

\section{Disclosure}

The authors declare that they have no competing interests.

\section{References}

1. World Health Organization. Consolidated Guidelines on the Use of Antiretroviral Drugs for Treating and Preventing HIV Infection; Recommendations for a Public Health Approach: Second Edition. World Health Organization; 2016.

2. Zhang F, Dou Z, Ma Y, et al. Effect of earlier initiation of antiretroviral treatment and increased treatment coverage on HIV-related mortality in China: a national observational cohort study. Lancet Infect Dis. 2011;11:516-524. doi:10.1016/S1473-3099(11)70097-4

3. Lourenço L, Samji H, Nohpal A, et al. Declines in highly active antiretroviral therapy initiation at CD4 + T-cells counts $\leq 200$ cells/ $\mu \mathrm{L}$ and the contribution of diagnosis of HIV at CD4 cell counts $\leq 200$ cells $/ \mu \mathrm{L}$ in British Columbia, Canada. HIV Med. 2015;16(6):337-345. doi:10.1111/hiv.12212

4. He L, Pan X, Dou Z, et al. The factors related to CD4+ TCell recovery and viral suppression in patients who have low CD4+ T-cell counts at the initiation of HAART: a retrospective study of the national HIV treatment sub-database of Zhejiang Province, China. PLoS One. 2016;11(2):e0148915.

5. Mulissa Z, Jerene D, Lindtjørn B. Patients present earlier and survival has improved, but pre-ART attrition is high in a six-year HIV cohort data from Ethiopia. PLoS One. 2010;5:e13268. doi:10.1371/journal. pone. 0013268

6. Mulu A, Liebert UG, Maier M. Virological efficacy and immunological recovery among Ethiopian HIV-1 infected adults and children. BMC Infect Dis. 2014;14. doi:10.1186/1471-2334-14-28

7. Asfaw A, Ali D, Eticha T, et al. CD4 cell count trends after commencement of antiretroviral therapy among HIV-infected patients in Tigray, Northern Ethiopia: a retrospective cross-sectional study. PLoS One. 2015;10(3):e0122583. doi:10.1371/journal.pone.0122583

8. Biset Ayalew M. Mortality and its predictors among HIV infected patients taking antiretroviral treatment in Ethiopia: a systematic review. AIDS Res Treat. 2017;2017:1-10. doi:10.1155/2017/5415298

9. Sorsa A. Predictors of sub-optimal CD4 recovery during the first six months of Anti-Retroviral Treatment (ART) in HIV infected children: a retrospective cross-sectional study from Tikur Anbessa Tertiary Hospital, Addis Ababa, Ethiopia. J Blood Lymphs. 2017;7(3):178. doi:10.4172/2165-7831.1000178
10. Engsig FN, Zangerle R, Katsarou O, et al. Long-term mortality in HIVpositive individuals virally suppressed for $>3$ years with incomplete CD4 recovery. Clin Infect Dis. 2014;58:1312-1321. doi:10.1093/cid/ciu038

11. Kahissay HM, Oga TT. Assessment of antiretroviral therapy (ART) outcomes versus CD4 cell count threshold among HIV/AIDS patients at ras Desta hospital, Addis Abeba, Ethiopia. JPSI. 2015;4(1):24-32.

12. Baker JV, Peng G, Rapkin J, et al. CD4+ count and risk of non-AIDS diseases following initial treatment for HIV infection. AIDS. 2008;22:841-848. doi:10.1097/QAD.0b013e3282f7cb76

13. Haile GS, Berha AB. Predictors of treatment failure, time to switch and reasons for switching to second-line antiretroviral therapy in HIV infected children receiving first-line anti-retroviral therapy at a tertiary care hospital in Ethiopia. BMC Pediatr. 2019;19. doi:10.1186/s12887-019-1402-1

14. Deyno S, Toma A, Taddesse F. Pattern and predictors of the cluster of differentiation 4 (CD4) cell count recovery among cohorts of the human immunodeficiency virus (HIV)-infected patients on antiretroviral therapy in Hawassa University Referral Hospital. J AIDS HIV Res. 2018;10:40-48. doi:10.5897/JAHR2017.0425

15. Anude CJ, Eze E, Onyegbutulem HC, Charurat M, Etiebet M, Ajayi S. Immuno-virologic outcomes and immuno-virologic discordance among adults alive and on antiretroviral therapy at 12 months in Nigeria. $B M C$ Infect Dis. 2013;13(113). doi:10.1186/1471-2334-13-113

16. Malaza A, Mossong J, Ba"rnighausen T, Viljoen J, Newell M-L. Population-based CD4 counts in a rural area in South Africa with high HIV prevalence and high antiretroviral treatment coverage. PLoS One. 2013;8:e70126.

17. Shastri S, Boregowda PH, Rewari BB, Tanwar S, Shet A, Kumar AMV. Scaling up antiretroviral treatment services in Karnataka, India: impact on CD4 counts of HIV-infected people. PLoS One. 2013;8(8):e72188. doi:10.1371/journal.pone.0072188

18. Siedner MJ, Ng CK, Bassett IV, Katz IT, Bangsberg DR, Tsai AC. Trends in CD4 count at presentation to care and treatment initiation in sub-Saharan Africa, 2002-2013: a meta-analysis. Clin Infect Dis. 2015;60:1120-1127.

19. Kiertiburanakul S, Boettiger D, Lee MP, et al. Trends of CD4 cell count levels at the initiation of antiretroviral therapy over time and factors associated with late initiation of antiretroviral therapy among Asian HIV-positive patients. J Int AIDS Soc. 2014;17:18804.

20. Reda AA, Biadgilign S, Deribew A, Gebre B, Deribe K. Predictors of change in CD4 lymphocyte count and weight among HIV infected patients on anti-retroviral treatment in Ethiopia: a retrospective longitudinal study. PLoS One. 2013;8(4):e58595. doi:10.1371/journal.pone.0058595

21. Loka JJ, Boscha RJ, Bensonb CA, et al. Long-term increase in CD4+ T-cell counts during combination antiretroviral therapy for HIV-1 infection. AIDS. 2010;24(12):1867-1876. doi:10.1097/QAD.0b013e32833adbcf

22. Nakanjako D, Ssewanyana I, Mayanja-Kizza H, et al. High T-cell immune activation and immune exhaustion among individuals with suboptimal CD4 recovery after 4 years of antiretroviral therapy in an African cohort. BMC Infect Dis. 2011;11(43). doi:10.1186/1471-2334-11-43

23. Pineda JA, Alcamí J, Blanco JR, et al. Hot immunological topics in HIV infection. J AIDS Clin Res. 2011;2(118). doi:10.4172/2155-6113.1000118

24. Prendergast A, Prado JG, Kang YH, et al. HIV-1 infection is characterized by profound depletion of CD161+ Th17 cells and gradual decline in regulatory T cells. AIDS. 2010;24:491-502. doi:10.1097/ QAD.0b013e3283344895

25. Federal Ministry of Health of Ethiopia. National guidelines for comprehensive HIV prevention, care and treatment. 2014.

26. Kebede MM, Zegeye DT, Zeleke BM. Predictors of CD4 count changes after initiation of antiretroviral treatment in the University of Gondar Hospital, Gondar in Ethiopia. Clin Res HIV/AIDS. 2014;1(2):1008.

27. Kyaw NL, Thanachartwet V, Kiertiburanakul S, et al. Baseline CD4 cell counts and outcomes among adult treatment naïve HIV patients after taking fixed-dose combination GPO-VIR-S and GPO-VIR-Z in Thailand. Southeast Asian $J$ Trop Med Public Health. 2013;44:232-243. 


\section{Publish your work in this journal}

HIV/AIDS - Research and Palliative Care is an international, peerreviewed open-access journal focusing on advances in research in HIV, its clinical progression and management options including antiviral treatment, palliative care and public healthcare policies to control viral spread. The manuscript management system is completely online and includes a very quick and fair peer-review system, which is all easy to use. Visit http://www.dovepress.com/testimonials.php to read real quotes from published authors.

Submit your manuscript here: https://www.dovepress.com/hivaids—research-and-palliative-care-journal 